\title{
Animal Rights: A Sociological Approach
}

\author{
Robert T. Hall
}

Ph.D., Sociology, University of Pittsburg, USA

Co-Director, Unidad de Bioética, Universidad Autónoma de Querétaro, México

Recommended citation. HALL R.T., Animal Rights: A Sociological Approach, dA. Derecho Animal (Forum of Animal Law Studies) 9/4 (2018) https://doi.org/10.5565/rev/da.353

Received: June 2018 Accepted: September 2018

\begin{abstract}
Building on the political perspective of Sue Donaldson and Will Kymlicka, I propose a sociological approach to animal rights, which takes the various types of human-animal relationships that have developed historically as the basis of current human obligations to members of other species.
\end{abstract}

Keywords: Animal rights, Animal law, Animal ethics, Sociology.

Resumen - Derechos de los animales: un enfoque sociológico

Siguiendo la perspectiva política de Sue Donaldson y Will Kymlicka, propongo un enfoque sociológico de los derechos de los animales, que toma los diversos tipos de relaciones humano-animales que se han desarrollado históricamente como la base de las obligaciones actuales de los seres humanos hacia los miembros de otras especies.

Palabras clave: Derechos de los animales, Derecho animal, Ética animal, Sociología. 


\section{POLITICAL PHILOSOPHY}

The supposition of this article is that both morality and the law are social constructs and that we use ethical perspectives to argue for or justify changes in the law. As a preface to the sociological approach that I offer below, I present first a brief account of a legalpolitical perspective to which my sociological approach is closely related.

Sue Donaldson and Will Kymlicka have developed a theory of animal citizenship that they have dubbed "Zoopolis". ${ }^{1}$ According to this perspective, citizens in democratic countries have three basic legal rights: 1) the right to live in a country, 2) the right to have their interests or welfare included in the political arrangements and 3) the right to participate in democratic institutions.

One important aspect of this perspective is the recognition that there are different types of citizenship status in western democratic societies. Full Citizens have all the rights of citizenship (or most of them). Permanent residents have the legal right to live in a place, but they lack voting rights. Visitors have time-limited rights to stay in a country, but in some countries they have the right to health care. Then there are documented and undocumented workers, indigenous communities, etc. Even political refugees have rights under international agreements.

Analogous to citizenship statuses, according to Donaldson and Kymlicka, different animals may claim certain moral rights according to their different types of relationships with humans. Animals are domestic pets, domesticated farm animals, refugees, or citizens of other territories. Farm-produced animals (domesticated) are different from family pets or domestic animals. Pets live in our families almost as family members; cows, chickens and pigs do not. Pets have privileges and responsibilities for "civilized" behavior. Like citizens, animals have the right to live in the country in which they were born, the right to have their interests or welfare included in the political arrangements and the right to participate in democratic institutions. For animals, of course, the right to participation would have to be exercised through guardians or organizations with standing to represent their interests. Donaldson and Kymlicka say:

We affirm that, as in the case of human beings, some animals are better seen as cocitizens in our political community whose interests count in the determination of our collective good; others are better seen as temporary visitors, or inhabitants who are not citizens, whose interests put restrictions on how we seek our collective good; and yet others (wild animals) are residents of their own political communities, whose sovereignty and territory we must respect. ${ }^{2}$

Liminal animals live on the boundary between human communities and nature; they are normally considered wild, but they live within or in proximity to the limits of cities, towns or farms and have become dependent on human communities. Within this category there are different types: some liminal animals are refugees - displaced by the invasion of their territories due to urban and agricultural development - while others have freely chosen to live close to humans for their own benefit and they perhaps could not survive in a totally wild environment. This is the case with pigeons, raccoons, rats or geese. People think that some of these animals can be tolerated or even welcome (like the pigeons or street cats that people feed, squirrels in public parks and in some places swans). Others are considered pests -- mice, rats, opossums, deer and sometimes squirrels and pigeons. The issue of liminal animals (neither wild nor domesticated) is complicated. Problems with animals that live in dependence on human beings include respect for the animals' freedom, protection of human beings and domestic animals from contagious diseases and from

\footnotetext{
${ }^{1}$ Sue Donaldson \& Will Kymlicka, Zoopolis: A Political Theory Of Animal Rights (2011).

${ }^{2}$ Ibid. 54.
} 
attacks. Cats, for example, are carnivores and cannot feed themselves unless they violate the moral rights of other species.

The objective of Zoopolis is the development of a form of co-existence and mutual support in a human-animal society. Donaldson and Kymlicka explain:

We are using 'citizenship theory' here in a broad sense to encompass all these questions about the notion of boundaries and membership of politically distinct communities, and therefore to incorporate questions about the rights to sovereignty and territory, regulation of international mobility, and access to citizenship of newcomers. ${ }^{3}$

The theoretical exercise that Donaldson and Kymlicka offer is extremely useful in two ways. First the attention they have given to the variety of human-animal relationships (domestic, domesticated, liminal, and wild) is a corrective to the simple wild/domesticated dichotomy that is frequently used animal ethics. Second, by their analogy with the contingencies of various types of citizenship, they have provoked reflection on the variety of human-animal relationships of coexistence that has to be considered. We have to discover new ways to treat the whole range of human-animals relationships fairly.

It will have to be noted, for example, that the fair treatment of animals cannot be based solely on species membership. Members of the same species can have different relationships with us. Cats can be either feral or domestic and companion dogs and seeingeye dogs have different privileges and responsibilities than house pets. "Feral dogs," according to Donaldson and Kymlicka, "need to communicate mainly with other feral dogs, but companion dogs need to communicate with humans and other species with which they coexist to function in a mixed human-animal society." 4

Once clarified, the concept of sovereignty would apply to wild animals in their own territories. There are, however, international principles that offer some parallels to relationships with sovereign wildlife communities. For example, in the field of international relations it is accepted that "if the people of a foreign state have suffered or are suffering a catastrophe (whether generated by human beings or by a natural event) and we are in a position to help and our efforts are not rejected, then we should help with the best of our ability and resources." 5

\section{A SOCIOLOGICAL PERSPECTIVE}

I propose to change the perspective from political science to sociology. From a sociological perspective, we do not start with the legal concept of citizenship status, but with the concept of moral obligation. In the moral sense, "obligation" has to do with the natural relationships between people. Legal arrangements such as citizenship come later and generally reflect moral obligations.

Moral obligations are social constructs that are based on historically developed social relationships - family first, then communities (including possibly religious obligations), then professions where people adopt different social roles and responsibilities, then nations and now global relationships. Each of these relationships is a field of study within sociology. As these relationships are assumed and develop, they give rise to moral obligations:

- Obligations to family: partners give mutual support and care for children;

\footnotetext{
${ }^{3}$ Ibid. 159.

${ }^{4}$ Ibid. 97.

${ }^{5}$ Ibid. 181.
} 
- Obligations to the community for education of children and for obedience to the laws that maintain social order;

- Obligations of employers for the control of workplace health and safety prohibiting child or slave labor and maintaining equal rights for women.

- Professional obligations of doctors, lawyers, teachers, priests and accountants to act on behalf of their clients interests;

- Obligations to one's country to pay taxes and serve in the military;

- And obligations to humanity to respect the sovereignty of other nations and to give aid in times of natural disasters.

Society itself is a web of historically constructed moral obligations. Law has a number of functions of guiding behavior, solving social conflict, promoting social values and maintaining order. In many of these functions the law formalizes moral obligations that have developed historically as people have increasingly coordinated their actions. ${ }^{6}$ "The law," as Oliver Wendell Holmes said, "is the witness and external deposit of our moral life. Its history is the history of the moral development of the race."7

\section{OBLIGATIONS TO ANIMALS}

Donaldson and Kymlicka take political relationships and various types of citizen and non-citizen status as their starting point. Then they propose that we think about animal moral and legal rights and obligations as based on, or analogous to, these various citizenship statuses and relationships. I believe that this relational perspective is key to animal ethics, but I think that the relationship between legal rights and moral obligations is the reverse. Instead of basing moral obligations to animals on legal rights related to civil status, it would be better to base an approach to animal rights directly on moral obligations derived from social relationships that are acquired at birth and developed historically.

In the course of human development, relationships and obligations to other species come right after the child's dependence on family and often before contact with the community. We have pets before we go to school and we teach children about animals as we teach them to talk and to read. The point is that social relationships and obligations come first. Citizenship statuses and civil rights are social constructions that formally establish and protect our various social relations. Laws specify our social obligations, but the obligations come first.

Laws protect (or sometimes inhibit) social relationships. In marriage and divorce, for example, people first form relationships, then they get married and this legalizes and protects the obligations that they have developed to one another. Then people may disagree and the relationship breaks down; then comes legal separation or divorce. And the law with respect to these social relations is still evolving. Gay and lesbian people have had relationships for centuries, but they have just recently acquired legal protection for their relationships. A lot of young people are now forming permanent relationships and having children without getting legally married. Their elders often think that they and their children need the protection of the law, but in many ways marriage laws have ceased to serve their function effectively. Responsibility for children remains a legal obligation, but the law can sometimes complicate marriage and divorce relationships.

The anthropologist Ralph Linton developed a simple typology of the social

\footnotetext{
${ }^{6}$ My perspective on the law is generally positivistic, but I believe that legal positivism is often misunderstood on the point of the historical development of morality and the law. See H.L.A. HART. (1961) The Concept of Law. Oxford: OUP and William C. Starr, Law and Morality in H.L.A. Hart's

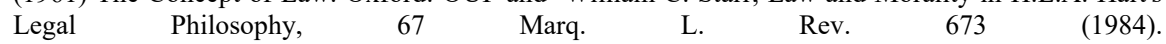
http://scholarship.law.marquette.edu/mulr/vol67/iss4/8

${ }^{7}$ Oliver Wendell Holmes, Jr., The Path of the Law.10 Harvard Law Review 457 (1897) 
attributes or statuses that individuals have. ${ }^{8}$ He made a distinction between social statuses that are given at birth or acquired at birth and statuses that are achieved later through peoples' efforts and activities. Being a son or daughter, or having brown eyes are innate states acquired at birth; becoming a doctor, teacher or student is a social status that is achieved later. And, sometimes, there are statuses that can be either acquired or achieved, such as being Catholic or Protestant, or having blond, brown or purple hair.

Obligations to animals are developed similarly through social relations. First there are acquired obligations that are due to nature of the animals in question. Animals are sentient beings with needs for opportunities to express their natural instincts. The natural status and characteristics of various animals are what Peter Singer ${ }^{9}$ and Martha Nussbaum ${ }^{10}$ say gives rise to moral obligations in human-animal relationship. And it is obvious that there are distinct types of animals with different characteristics and abilities; so we need studies of physiology, neurology, and animal behavior to better understand the natural characteristics and our obligations that arise from them.

Secondly, however, and this is the point I want to emphasize, there are obligations that are due to the social relations that humans have created with animals. There are various types of historical relationships that have been developed or achieved. Parallel to Linton's distinction, there are human-animal relations that are acquired at birth - natural obligations that are associated with statuses inherited at birth. But animals are also adopted by humans and achieve or gain new relationships. People adopt pets. It is interesting that we use the term "adoption" for pets but not for other animals. You only "buy" a cow or a chicken, you don't "adopt" a cow or chicken. And since many pets cannot survive in the wild, the owner who adopts an animal as a pet assumes corresponding obligations for its care; the relationship carries obligations. And it can be said that when a pet gives birth, the owner also owns the offspring and he or she acquires new obligations.

Some animal rights advocates insist that animals are not "owned" in the sense that property is owned, because they are sentient beings. But it cannot be denied that some animals, even as sentient beings, are indeed owned. So the currently vague legal concept of sentient beings cannot exclude many of the implications of the traditional concept of ownership. Pets, as domestic animals, can be said to have some rights based on the obligations of their owners and the offspring of domestic animals acquire rights based on the obligations of the owner as well. I continue to use the concept of ownership to imply some of these obligations -- but perhaps only until a better concept is developed.

Animals produced for food clearly do not have the legal rights of domestic pets, but they do have, or at least should have, rights as domesticated animals. This is a distinction that is already established in law in many jurisdictions, but the relationship of domestication is not taken seriously and this gives rise to a great injustice. Domestication is a relationship between humans and animals that was socially constructed millennia ago. But the relationship continues generation after generation. Domesticated animals serve human needs and in return humans take care of domesticated animals. This was more obvious before the age of factory farms and mass production when farm animals were really cared for. Modern mass production of meat has ignored or denied this relationship. Humans have walked away from their obligations and betrayed the trust of the animals that they domesticated in the first place. Animals that are domesticated cannot survive in a natural state, outside the confines of their relationships with humans. Their owners have obligations and anyone who has inherited or bought farm animals has obligations derived from the relationship of domestication.

We humans, of course, are not only animals; we are domesticated animals. Anyone who has raised children knows how difficult it is to domesticate them as infants - and it

\footnotetext{
${ }^{8}$ Ralph Linton, The Study of Man: An Introduction (1936).

${ }^{9}$ Peter Singer, Animal Liberation (Second Edition) (1990).

${ }^{10}$ Martha Nussbaum, Frontiers of Justice: Disability, Nationality, and Species Membership (2006).
} Derecho Animal. Forum of Animal Law Studies, vol. 9/4 
gets even more problematic when they are teenagers. We acquire the obligation to domesticate the next generation by the act of having children. Similarly, anyone who owns a domestic or domesticated animal acquires obligations when they inherit or purchase or adopt an animal or when they allow it to reproduce.

Domestic and domesticated animals have both acquired and achieved relationships. Other relationships are less intentional. Some animals are displaced by urban development or infrastructure construction or agriculture and become refugees. These animals acquire moral rights based on the obligations of the human beings that have destroyed their habitat. Human beings have restitution or liability obligations. Then there are various types of animals that depend on human civilization: pigeons, squirrels, raccoons, mice, etc. It seems that they have adopted us rather than we adopting them. It is perhaps unclear, therefore, what obligations these relationships carry; but perhaps these liminal animals should be recognized as constructing social relationships with us. And finally, our obligations to animals that want nothing to do with human beings have to be considered. They are, indeed citizens of other countries, but they are sometimes in need of help and have some claim to human foreign aid as inhabitants of the same planet.

\section{CONCLUSION}

To understand human-animal relations, we perhaps should not start with a discussion of animal rights laws or citizenship status. These are highly developed social constructs. We should start with the relationships that have grown up historically and socially and consider the obligations and responsibilities that are implicit in these relationships.

I would suggest that, in terms of contemporary ethical theory, this perspective is quite similar to a feminist perspective: morality develops, at least in part, out of networks of the many types of human relationships that we have. ${ }^{11}$ So the moral argument for more humane treatment of animals and for establishing legal rights of animals can be based on the historically acquired obligations of the various relationships between human beings and nonhuman beings.

I initiated this discussion with a deep appreciation of Sue Donaldson and Will Kymlicka's ideas about animals as citizens. But then I suggested that we look beyond or behind this to the obligations that we have because we have a number of historically constructed relationships with animals: we have domesticated some of them; others are domestic pets and others we have displaced from their normal habitat by farming or urban development. The important difference between Donaldson and Kymlicka's perspective and this account is that theirs is largely an analogy - an adaptation of concepts of political philosophy. The social construction perspective is more direct. Historically developed social relationships are facts, not analogies or similarities. To advocate social and legal change we really have to talk about facts. We need to take the concept of "sentient beings" and develop it in terms of the historical relationships and obligations that we have had and still have with our fellow creatures on this planet.

\section{BIBLIOGRAPHY}

- Donaldson, Sue and Kymlicka, Will. (2011). Zoopolis: A Political Theory of Animal Rights. New York: Oxford University Press.

- Linton, Ralph. (1936). The Study of Man: An Introduction. New York: Appleton.

- Nussbaum, Martha. (2006). Frontiers of Justice: Disability, Nationality, and Species Membership. Cambridge: The Belknap Press.

\footnotetext{
${ }^{11}$ Carol Gilligan. In a Different Voice. Cambridge, MA: Harvard University Press. 1982; M. J.

Larrabee, Editor. An Ethic of Care. New York: Routledge. 1993.
} 
- Singer, Peter. (1990). Animal Liberation (Second Edition). New York: The New York Review of Books. 